\title{
Cash flow ratios: Efficient measures of performance of selected companies in Oman
}

\author{
Dr. M. Krishna Murthy ${ }^{1,}$ Muneer Ahmed Al Mahrooqi ${ }^{2,}$ Najlaa ALMajizi ${ }^{3}$, Ramla Mohammed ${ }^{4,}$ \\ Shatha ALManhi ${ }^{5}$ and. Buthaina ALSiyabi ${ }^{6}$ \\ ${ }^{1}$ Faculty, University of Technology and Applied Sciences, Higher College of Technology, Sultanate of Oman \\ 23456 Bachelor Students, University of Technology and Applied Sciences, Higher College of Technology, Sultanate of \\ Oman
}

\begin{abstract}
This study is very important as the study is carried out with an objective of measuring liquidity, solvency, and profitability of five different companies for five different years from different industries. It is believed that the study would be most appropriate for the users to understand and identify the strengths and weakness of the financial positon of the companies to take a decision of investment. The study has used nonprobability sampling to select the companies and to measure with the help of traditional ratios namely Current ratio, Quick ratio, total assets to total liabilities, times interest earned ratio and profit margin ratio as part of the traditional ratios and operating cash flow ratios, cash flow to debt ratio and cash flow margin ratios as part of cash flow ratios. Pearson's correlation coefficient also measured to find the relationship between traditional and cash flow ratios for selected company. It is found that cash flow ratios are better when compared to traditional ratios and in some cases traditional ratios are better than cash flow ratios. It is also suggested that the company must improve when the ratios are weak, and they should maintain the consistency with the ratios to show strong financial health. It is sure that the investors would be happy to take decision by using the financial statements and the analysis through the ratios as well.
\end{abstract}

Keywords-Cash Flow, Traditional Ratios, Cash Flow Ratios, Liquidity Position

\section{INTRODUCTION}

Cash flow is one of the most important statements of a company's financial statements. Cash flow analysis with the help of ratios would help to measure the performance efficiently of an entity for a specific period. This specific study would focus to understand the state of liquidity, solvency, and profitability of the selected companies for a period of five years for five selected companies in Sultanate of Oman. This study would give attention on the cash flow ratios with which a reader can easily understand and interpret the cash inflows and outflows of those companies the investor wishes to understand and invest. The main purpose of this research is to introduce the cash flow ratios and their role in indicating the liquidity, solvency and profitability of different companies selected in Sultanate of Oman. Moreover, the study aims to analyze and compare the cash flow ratios and traditional ratios in estimating the liquidity, solvency, and profitability of the five different Omani companies. The results of this study would help to give a clear picture for the users on estimating the performance of the companies considered for the study.

\section{STATEMENT OF THE PROBLEM}

The key question which every stakeholder should ask before taking any decision is if this entity has the full knowledge and experience to deal perfectly with financial liquidity, solvency, and profitability of the entity. It is important to take a decision relating to the financial performance of any company, the stakeholders would investigate the financial statements of those companies selected for the investment. This is not enough to know as the company deals with the cash in day-to-day life and cash flow statements would give a clear picture of cash inflow and outflow which helps to understand the liquidity, solvency, and profitability position of a company. This is the main issue that faced by every stakeholder which Influence them to choose the right decision. In addition, the analysis with the help of relevant cash flow ratios and traditional ratios would help to understand the status of those selected companies in detail. Consequently, our study aspires to educate the stakeholders with comparison of both cash flow ratios and traditional ratios.

\section{AIMS AND OBJECTIVES OF THE STUDY}

Aim of the study is to compare the traditional ratios and cash flow ratios of certain selected companies from various industry and it is decided to cover the existing gap by going through the literature reviews on the similar topics. It is also identified that there are very few studies on cash flow statement and its analysis such as Baki Billah et al 2015 on Liquidity analysis of selected public listed companies in Malaysia have described the relationship as positive 


\title{
International Advanced Research Journal in Science, Engineering and Technology
}

\author{
Vol. 8, Issue 8, August 2021
}

\section{DOI: 10.17148/IARJSET.2021.8826}

significant relationship between cash flow ratios and traditional ratios. This study would help to add as guide to the users and for the future research students. Furthermore, most of the users would not get the results of cash flow analysis through cash flow ratios and traditional ratios and this study would also help them to exactly understand the real significance behind cash flow statement by considering the companies selected for the study. So, the research study is focused to spread awareness of this subject among the users of the financial statements to make future decisions with the help of both traditional and cash flow ratios. The objective of the study is to analyze the liquidity position of selected companies in Oman through cash flow ratios, to examine the solvency position of selected companies in Oman through cash flow ratios, to measure the profitability position of selected companies in Oman through cash flow ratios and to compare the cash flow ratios and traditional ratios on liquidity, solvency, and profitability of selected companies in Oman.

\section{REVIEW OF LITERATURE}

Studying financial performance of the companies selected for the study are not new, there are thousands of publications on this study. Every study is different by using different (independent variables) in the form of ratios developed by the researcher to arrive results. Few examples are Horrigan (1965) in one of the oldest studies depicted that finding financial performance is essential to run any business. Ross, Westerfield and Jordan 2003 also highlighted the importance of tradition ratios which measures the multilevel company's performance, projecting information to attract customers. (DeFranco and Schmidgall 1988 argued that cash is not only the variable to be considered for the survival and they have highlighted that many factors affect in the short run.

Porwal H K and Jain S 2013 proposed a study to find the issues in conventional ratios and incorporated their view that a successful company is one which makes more and more cash to meet their daily operating expenditures, repayment of current liabilities, purchase of short-term current assets, pay taxes and dividend. Armen Stephanyan 2013 found that the airlines company faces liquid problems and faces difficulties in making cash to pay off its unexpected expenditure and other current liabilities.

Some of the studies about cash flow ratios have witnessed and pointed out that the cash flow statements and analysis with the help of cash flow ratios are much important for any industry to take valuable decisions such as (Bect1994, Bohannon and Edwards 1993, Casey and Bartczak 1985, DeFranco and Schmidgall 1988, Epstein and Pava 1994, Mills and Yamamura 1998, Schmidgall, Geller and Ilvento 1993, Sylvestre and Urbancic 1994. Beck1994 argued that the cash is King of every business and that would determine the success and failure of a business entity.

Traditional ratios are used to determine the financial performance of the activities for a very long period as stakeholders like investors, suppliers and internal management always depend. Authors have observed that these traditional ratios help them to take a decision by simply looking the results in its Andrew and Schmidgall 1993. Few authors were in the opinion that the traditional ratios are the key techniques for analyzing the short-term credit worthiness of a company for a long Giacomino and Mielke 1993. Yamamura 1998 argued that the accrual basis of accounting may be followed with the requirement of generally accepted accounting principles, but cash flow ratios are also important to analyze the risk related to the investments. Moreover, studies like DeFranco and Schmidgall 1988, McGowne 1989, Mills and Yamamura have argued that the internal and external stakeholders considered traditional ratios are the tools to take a decision. Whereas Zelloer and Stanko 1994 varies in the opinion that they argued that the traditional ratios failed to show the severe liquidity problems in banking sector.

Financial ratio analysis has been extensively employed to assess the financial performance of operations for a long time by investors, creditors, and managers. It permits them to obtain more valuable information from financial statements than they can receive simply from reviewing the absolute numbers reported in the documents (Andrew \& Schmidgall, 1993). (Ross Kirkham 2012) examined the efficiency of the company with comparison of traditional and cash flow ratios. The study was carried out to analyze the liquidity of companies those using traditional ratio when compared to cash flow ratios. Few companies were taken for the study and the study concluded that there are differences leading the incorrect forecast and decisions by using traditional ratio as the one of the ratios showed the company is liquid but in fact the company was facing cash flow issues, and, in some cases, it was observed that the company was not liquid when the cash flow resources are sufficient to handle.

Rifki (2010), "identifying the performance of company is one of the important activities which helps to prevent risk and find risk management strategies. The study concluded that finding imbalance between assets and liabilities and assessing risk of liquidity in a company is very important to understand the financial position of an entity." Jooste (2006), " the cash flow statement is an integral part of any financial statements and authors have argued that the analysis of cash flow is essential tool for any assessment and they have pointed out so far there were no concrete researches in analyzing financial statements with the help of cash flow ratios which are important." According to Durrah (2016),"The purpose of this study is to study the relationship between the indicators of the financial performance and liquidity ratios 


\title{
International Advanced Research Journal in Science, Engineering and Technology
}

\author{
Vol. 8, Issue 8, August 2021
}

\section{DOI: 10.17148/IARJSET.2021.8826}

in the food company and the outcome of this study is presented that no relationship between all the liquidity ratios and the gross profit margin. On other hand there are optimistic relationship between the current ratio and all the profit margins. Moreover, there are links or relation between the return on assets and the liquidity ratio". Sulayman H Atieh 2014 analyzed the liquidity position of pharmaceutical sector and observed the cash flow ratios much relied on than the traditional ratios. Cash flow ratios provide better liquidity status of the companies selected for the study.

\section{RESEARCH GAP AND RESEARCH METHODOLOGY}

There were too many studies on liquidity management on banks (Saraceno 1949, Caprara 1954, Cutolo 1968, Cesarini 1982, Baravelli 1989, Ferrari 1988, Fabrizi et al 1990, Gabbi 1992, Ruozi 1994, Banja et al 1999. Coltman and Jagels 2001 have formed a view that liquidity analysis by using cash flow statement is more reliable than financial performance and financial position. Cash flow ratios are significant to evaluate the company's performance than traditional ratios. in addition, most research was foreign studies in contrast there are several studies in Oman. Therefore, in this project we will try to cover this gap as possible to meet all the objectives framed in this study considering the data for five years with different companies selected from the study. Research methodology is an important part of any research study in which it outlines the way in which the research should travel. It outlines step by step process to complete the research work systematically without flaws. The sources of the data and the uses of such data is a vastly important step in the beginning of research layout. Without data it is impossible to conduct any research. The methods of collecting data have major impact on the quantity and quality of data. Generally, researchers try to utilize the most suitable methods for collecting the data for the projects to improve it to a standard and to reach the objectives framed in the study. This chapter clarifies the research methods and data collection methods.

The objectives of the study are based on determining the liquidity, solvency, and profitability status of the selected company. The study was carried out to liquidity of traditional ratios in the form of current ratio, quick ratio and to measure the liquidity of cash flow ratios in the form of operating cash flow. Moreover, to study the solvency of traditional ratio in the form of total assets to total liability ratio and times interest earned ratio. To measure the profitability position of traditional ratios in the form profit margin ratio and to measure the profitability of cash flow ratios in the form of cash flow margin ratio. Simple correlation coefficient has been calculated to arrive the relationship between traditional and cash flow ratios. Pearson's Correlation is measuring the coefficients which help to identify the strength of the variables taken for the study. Pearson's Correlation helps the researcher to find the relationship between the variables from -1 to +1 which shows 1 is positive correlation, -1 is negative correlation and 0 is no correlation.

\section{DATA ANALYSIS}

Current ratio of Al Jazeera Services for the first three years are less than the ideal Ratio of 2 and 2.78 for the year 2016 and 2.93 for the ear 2017. Bank Muscat has less than ideal ratio of 2 for all the five years of the study period. Current Ratio of the Muscat insurance has been above 2 which an ideal ratio which gradually decreases from 4.40 to 2.49 . The current Ratio of the National Gas Company has the current ratio of less than 2 for all the five years. Oman Cement has been having current ratio of more than ideal ratio of 2 for all the five years. Quick Ratio of the of Al Jazeera Services for the five years are more than ideal ratio of 1 and during the last two years the ratio has improved much more than the past. Bank Muscat also maintain the ideal Quick Ratio of 1 and in the case of Muscat Insurance the Quick Ratio has been found higher when compared to all the five companies during the five years. National Gas company has not met the ideal ratio of 1 and Oman cement company ensures the ideal ratio with good quick Ratio.

Al Jazeera services less than 1 ideal ratio operating cash flow ratio which gradually increases during the first four years, Bank Muscat has less than 1 which is ideal ratio, Muscat Insurance Company has also been observed that all the five years in which the study has been analyzed the ratios are less than ideal ratio of 1. Operating cash flow ratios of Bank Muscat, Muscat Insurance and National Gas companies are less than 1. Oman Cement Company has ideal ratio of more than one for all the firs four years except the fifth year 0.99. Operating cash flow ratios of the Al Jazeera services, Bank Muscat, Muscat insurance and National Gas Company have arrived with less-than-ideal ratio of 1 . It is important to find out the operating cash flow ratios which give original situation of the companies which deals with cash. It is observed from the calculation of Pearson's coefficient of correlation, that there is strong relationship between the current ratio and cash flow ratio of Al Jazeera company which shows the liquidity position of the company.

Al Jazeera Company and Oman cement is having higher ratios of total assets to total liabilities when compared to other companies. It shows stronger assets back up for the liabilities the company owes. Bank Muscat, Muscat Insurance company and National Gas company is having ratio almost same around 1 which shows the total assets are in better position to pay off the liabilities. Higher the ratio is the better the position of the company to maintain the cash through operating activities to pay off its obligations. Bank Muscat has negative cash flow operations to debt ratio during the 


\title{
International Advanced Research Journal in Science, Engineering and Technology
}

\author{
Vol. 8, Issue 8, August 2021
}

\section{DOI: 10.17148/IARJSET.2021.8826}

year 2013 and 2017 shows weaker cash position to pay off its debt and Muscat insurance companies during 2014 was negative which shows weak position with negative rations. Al Jazeera company services, Muscat Insurance company, National Gas and Oman Cement companies shows positive ratios but not higher ratios.

From the correlation coefficient of solvency ratio of Al Jazeera company, it is found there is strong relationship between traditional and cash flow ratios. Al Jazeera services company shows the profit ratios for the first five years which gradually decreased during the first five years from 0.4600 to 0.2124 . National Gas company shows a negative ratio of - 0.0135 during 2015 which has recovered slowly during the years 2016 and 2017. Oman Cement company, Muscat insurance company and Bank Muscat shows the profit with alternative increase and decrease. Cash flow margin ratio of the Al Jazeera Company gradually decreases during the five years; Bank Muscat ratio also decreases during the second year and increases during the third year and subsequent decrease during the next two years. Oman Cement Company shows fluctuations in the cash flow margin ratios in alternative years. Correlation coefficient shows there is very strong positive correlation between the traditional ratios and cash flow ratios.

\section{CONCLUSION}

The findings of the study entitled on cash flow ratios an efficient measure of performance of selected companies in Oman have been analyzed with the help of both traditional ratios and cash flow ratios. The study has taken five companies for a period of five years to assess the liquidity, solvency, and profitability. Traditional ratios are followed by every organization for so many decades for analyzing company position and performance. Cash flow ratios are one of the efficient measures for researcher to conclude on liquidity, solvency, and profitability. Cash flow ratios give more information than the traditional ratios that helps to pay off the obligations. It is better to use both the types of the ratios to measure the performance of companies as these ratios would give signal for the companies and for the investors to manage their commitments.

\section{RECOMMENDATIONS}

Bank Muscat, National Gas Company has current ratio of less than 2 for all the five years of the study period which is to be improved as the current ratio is very important to pay off its current liabilities. Current ratio of Al Jazeera services must be maintained as the ratio for the first three years are less than ideal ratio of 2 and the company managed to maintain the ideal ratio for the year 2016 and 2017 respectively. National Gas Company has not met the required ideal quick ratio of 1 as their ratios for all the five years were less than 1. Bank Muscat and Al Jazeera company have been satisfied the quick ratio criteria and Oman Cement company and Muscat insurance Company have higher Quick Ratio which improved the repaying capabilities of short-term liabilities during the five years of the study period. It is important for the companies to meet the ideal ratios to be in safer side at the time of unexpected situations.

It has been observed that the cash flow ratios signal the company on the weak liquidity position which would be difficult for them to manage unforeseen situations in the company. Whereas the quick ratios of the companies for the five years have been analyzed and found that national gas company fails to maintain the liquidity which is evident from the quick Ratio which is a traditional way of analyzing and with operating cash flow ratios under the cash flow ratios. Therefore, both traditional ratios and cash flow ratios would be used to analyze the liquidity position of the company. Bank Muscat shows manageable times interest earned ratio and National Gas company for the first two years the ratio was less than which shows risky position to pay off its debts but the same has been recovered subsequently in the next three years showing strong financial position.

It is important for the National Gas company to maintain the times interest earned ratio consistently to show the strong financial position. The ratio at least should be more than one to show that the entity is able to pay the debts at the safer side. It is suggested that the total assets to total liabilities ratios should be higher which would show a stronger position. Higher the ratio is healthy the company and lesser the ratio shows more liabilities over the assets of the company. The Bank Muscat and Muscat insurance companies should maintain the cash flow from operating activities which shows negative ratios during certain years. Other companies also should maintain adequate cash from activities to pay off its liabilities and to give more confident to the investors.

Solvency position through traditional ratios such as times interest earned ratio, total assets to total liabilities ratio and cash flow ratios of cash flow from operations to liabilities ratios have been incorporated in the study. Cash flow operations to debt ratios shows weaker ratios and traditional ratios shows much stronger position that the cash flow ratios. All the companies under the study have positive cash flow ratios and higher the cash flow margin ratio is better the position of the companies, and it is important that the companies should maintain and develop the cash flow margin ratio which would give confident to the investors to select for their preferred investment. 


\title{
International Advanced Research Journal in Science, Engineering and Technology
}

\author{
Vol. 8, Issue 8, August 2021
}

\section{DOI: $10.17148 /$ IARJSET.2021.8826}

\section{REFERENCES}

1. Andrew W P and Schmidgall R S, 1993, Financial management for the hospitality industry, Educational Institute of the American Hotel and Lodging Association.

2. Akter A, Mahmud K, 2014, Liquidity profitability relationship in Bangladesh banking industry, International Journal of empirical finance, Pp.112.

3. Armen, Stempanyan 2013, Performance assessment of major United States Airlines via cash flow ratios, Journal of the faculty of economics, University of Oradea, Pp.398.

4. Baki Billah N.M et al 2015, Liquidity analysis of selected public listed companies in Malaysia, international Journal of economics and business, Pp.2.

5. Bhandari S B and Iyer R, 2013, Predicting business failure using cash flow statements based measures, managerial finance, Pp.667.

6. Beck D 1994, Cash is King, Health care supervisor, Volume, No.13, Pp1-9. Bohannon J and Edwards D 1993 , Cash budgeting, Journal of property management, Volume 58, Pp.52-53.

7. Casey C and Bartczak N 1985, Using operating cash flow data to predict financial distress:Some extensions, Journal of accounting Research, Volume (1), Pp.23

8. DeFranco A L and Schmidgall R S 1998, Cash flow practices and procedures in the lodging industry, Journal of Hospitality and Tourism Research, Pp.72-73.

9. Dwolabi S A and Obida S S, 2012, Liquidity management and corporate profitability: Case Study of selected manufacturing companies listed on the Nigerian stock exchange, Business management dynamics, Pp.10

10. Epstein M C and Pava M L 1994, profile of an annual report, Financial Executive, Volume No.10(1), Pp.41-43.

11. Giacomino D E and Mielke D E, 1993, Cash flows: Another approach to ratio analysis, Journal of accountancy, Pp.55-58.

12. Horrigan J O 1965, Some Empirical Bases of Financial Ratio Analysis, The Accounting Review, Volume 40, Pp.558.

13. Leonie Jooste, cash flow ratios as a yardstick for evaluating financial performance in African Business, Emerald Group Publishing limited, Pp. 56.

14. McGowne L R 1989, Cash flow statements in the hospitality industry, Bottomline, Pp.20.25.

15. Mills J R and Yamamura J H, 1998, The power of cash flow ratios, Journal of accountancy, Pp.53.

16. Omar Durrah, Abdul Aziz Abdul Rahman, Syed Ahsn Jamil, Jour Aldeen Ghafeer, Exploring the relationship between liquidity ratios and indicators of financial performance:

17. An analytical study on food industrial companies listed in Amman Busra, International Journal of economics and financial issues, Pp.23

18. Parnal H K of Jain, Shashank 2013, Cash flow ratios to predict investments soundness, Asia, Pacific Finance and accounting review, Pp.55.

19. Porwal H K and Jain 2013, Statement of cash flows: Some desired improvements,Emerging issues in accounting, business and management, Pp.28-29.

20. Rifki 2010, Assessment of liquidity management in Banking industry, Emerald group publishers, Pp.65.

21. Ross Kirkham 2012, Liquidity using cash flow ratios and traditional ratios: The telecommunications sector in Australia, Journal of new business ideas and trends, Pp.10.

22. Ross S A, Westerfield R. W and Jordan B D, Essentials of corporate finance, 4th edition, McGraw Hill, Pp.98.

23. Schimidgall R S, Galler A N, and Ilvento C, 1993, Financial analysis using the statement of cash flows, Cornell Hotel and Restaurant Administration Quarterly, Pp.46.47.

24. Sulayman H Atieh 2014, Liquidity analysis using cash flow ratios as compared to traditional ratios in the pharmaceutical sector in Jordan, International journal of financial research, Pp.146-147.

25. Sharath A.M. "The Challenges of Poverty, Types and Its Causes". International Research Journal on Advanced Science Hub, 2, Special Issue ICAMET 10S, 2020, 81-85. doi: 10.47392/irjash.2020.203

26. Sylvestre J and Urbancic F R 1994, Effective methods for cash flow analysis, Healthcare financial management, Pp.62.64.

27. Zeller T L and Stanko B B 1994, Operating cash flow ratios measure a retain firm's ability to pay, Journal of applied business research, Pp.51.

28. Vijayalakshmi S.; Arpanaa S. "Cash Conversion Cycle of food and beverage Product industry". International Research Journal on Advanced Science Hub, 3, Special Issue 6S, 2021, 37-41. 